95

\title{
CROSSROADS OF WAR: THE PEOPLE OF NKANDLA IN THE ZULU REBELLION OF 1906
}

\author{
Prof Paul S. Thompson \\ School of Anthropology, Gender \& Historical Studies, \\ University of KwaZulu-Natal
}

\begin{abstract}
... [T] ... a message so strongly worded as to leave no loophole for Sigananda in case ... he was knowingly assisting or harbouring Bambata. The dire result of such action on his part, i.e. ruination by confiscation of property and the practical extermination of the tribe were pointed out and every conceivable pressure, as far as reasoning powers went, were brought to bear on him. (Benjamin Colenbrander, Resident Magistrate, Nkandhla Division, writing in 1906) ${ }^{1}$
\end{abstract}

\section{The rebellion and Nkandla}

The Zulu Rebellion of 1906 was the violent response to the imposition of a poll tax of $£ 1$ on all adult males (with exempted categories) by the government of the British South African colony of Natal on the part of a section of the indigenous, Zulu-speaking people. The rebellion was in the nature of "secondary resistance" to European colonization, and the poll tax was only the immediate cause of it. Not all the African people (who made up $82 \%$ of the colony's population) participated in the rebellion; only a few did, but there was the potential for a mass uprising, which inspired great fear among the European settlers (who made up just 8,3\% of the population) and prompted the colony's responsible government to take quick and vigorous action to crush the rebellion before it could spread. The object of the

\footnotetext{
1 “An Account of the Zulu Rebellion of 1906: The unofficial Report of Benjamin Colenbrander, Resident Magistrate of the Nkandhla Division, Province of Zululand," in Natalia: Journal of the Natal Society, No. 35 (December 2005), p. 15. (Hereafter cited as Colenbrander, and all other books and articles will also be cited after the first instance by their authors' names.)
} 
rebels, beyond the removal of the poll tax, was to drive the white settlers out of the country and to restore the pre-colonial regime, although it was unclear just what they thought that might have been. In the case of most (but not all) of the those living in the Province of Zululand, i.e. the northeastern quarter of the Colony of Natal, it meant the restoration of the Zulu monarchy under the chief Dinuzulu.

The rebellion had three phases. First, there was an attack on the police near Richmond in February, with implications of a wider outbreak in the South of the Colony, which was forestalled by the expedition of a colonial field force in the area in March. Second, there were attacks in the Umvoti Division in April, similarly checked, but the leader, Bhambatha (the rebellion is often called "Bhambatha's Rebellion"), transferred activity to the Nkandhla Division in Zululand, where the rebellion became a war and was suppressed with great effort and difficulty by the colonial government in June. Third, a futile insurrection in the Mapumulo Division was put down quickly in June and July. It is the second phase, "Bhambatha's Rebellion", which concerns us here.

Bhambatha is an icon of resistance to colonization. The centenary of the rebellion was marked by a series of public events which reached a climax at Mpanza, near Greytown, on June 11, 2006. The president of South Africa, the premier of KwaZulu-Natal, and the king of the Zulu nation, and many other notables gathered to pay homage to the leader of the rebellion and to witness his posthumous reinstatement as head of his people, reversing his deposal by the colonial regime. ${ }^{2}$ In the keynote speech President Thabo Mbeki told the crowd: "To pay tribute to inkosi Bhambatha, we need to defend our freedom, the freedom he fought for."3 Bhambatha thus entered the pantheon of Struggle heroes officially. In September he was awarded The Order of Mendi for Bravery in Gold "for leading a rebellion against the repressive laws of the colonialist government and for laying down his life for the cause of justice". The premier's office and provincial department of education sponsored a series of newspaper supplements entitled Remembering the

${ }^{2}$ Republic of South Africa, Department of Arts and Culture, and KwaZulu-Natal Provincial Government, Saluting our heroes and celebrating a rich heritage in KwaZulu-Natal 2006: Public Launch[,] Bhambatha Centenary Commemoration, and Age of Hope: Through Struggle to Freedom: Saluting our Heroes: Reinstating Inkosi Bhambatha (both 2006).

${ }^{3}$ The Sowetan, June 12, 2006: "Rivals Stand United."

${ }^{4}$ The Witness, Sept. 27, 2006: "Mbeki honours KwaZulu-Natal's greatest with National Orders." 
Rebellion, ${ }^{5}$ and no less than three musical plays were staged in connexion with the commemoration of the rebellion. ${ }^{6}$

Yet the centenary brought forth little in the way of scholarly literature on the subject. The newspaper supplements were collected in a book, Remembering the Rebellion: the Zulu Uprising of $1906,{ }^{7}$ but it is aimed at the schools. There was also the unique Freedom Sown in Blood: Memories of the Impi Yamakhanda: An Indigenous Knowledge Systems Perspective, ${ }^{8}$ the result of an oral history project at Mpanza, but it contains practically no information on the rebellion. And that is all.

In fact the historical literature is pretty sparse. Apart from the abovementioned books, it includes only two magisterial works and a handful of monographs and articles. The classics are James Stuart, A History of the Zulu Rebellion of 1906 and of Dinuzulu's Arrest, Trial and Expatriation (1913), and Shula Marks, Reluctant Rebellion: The 1906-1908 Disturbances in Natal (1970). ${ }^{9}$ Stuart's book is regarded as the official history, but it is much more than an apologia. Marks' is a radical history, sustained by extensive use of archival records.

During the last fifteen years a number of monographs concerning the rebellion have appeared. John Lambert, Betrayed Trust: Africans and the State in Colonial Natal (1995) and Benedict Carton, Blood from Your Children: The Colonial Origins of Generational Conflict in South Africa (2000) focus principally on the antecedents. Lars Berge, The Bambatha Watershed: Swedish Missionaries,

5 Twelve supplements, March 23 - July 13, 2006, in Ilanga, UmAfrika, and The Witness.

${ }^{6}$ The Mercury, Nov. 10, 2006: "War, song and dance."

${ }^{7}$ Pietermaritzburg, University of KwaZulu-Natal Press, 2006.

${ }^{8}$ Thohoyondou, Ditlou Publishers, 2006.

${ }^{9}$ Published by Macmillan (London) and the Clarendon Press (Oxford), respectively. I would contend that the true official account is The Natal Rebellion (London, Longmans, and Cape Town, Juta, 1907), by Colonel McKenzie's staff officer Walter Bosman, although it is not interpretive. Also without interpretation is The Natal Native Rebellion as told in Official Despatches From January $1^{\text {st }}$ to June $23^{\text {rd }}$, 1906 (Pietermaritzburg, Davis, 1906; hereafter cited as OD; also published in The Natal Government Gazette, No, 3568A of October 2, 1906). Also excluded is Andreas Z. Zungu, USukabekuluma and the Bhambatha Rebellion (1933 Zulu edition translated by A. C. T. Mayekiso; Durban, University of Durban -Westville, 1997), a secondhand memoir that reads more like a picaresque novel, and is lacking contextualization and interpretation. 
African Christians and an Evolving Zulu Church in Rural Natal and Zululand 19021910 (2000) is insightful but obviously limited in scope. ${ }^{10}$ Jeff Guy, The Maphumulo Uprising: War, Law and Ritual in the Zulu Rebellion (2005), ${ }^{11}$ and P. S. Thompson, Bambatha at Mpanza: The Making of a Rebel (2004) and Incident at Trewirgie: First Shots of the Zulu Rebellion 1906 (2005) are phase (and area) specific. The latter's An Historical Atlas of the Zulu Rebellion of $1906(2001)^{12}$ may be regarded as a work in the "companion-to" genre. All of these books, as well as the handful of articles, ${ }^{13}$ are useful in their way, but there is no doubting that Marks' dominates the field.

Several reasons may be adduced to explain the dearth of historical literature. First, there is the nature of the rebellion itself. Sudden, unnerving and bloody, there is little in it for either side to be proud of, and in that sense it is better forgotten. Second, the advent of the Union of South Africa soon after the rebellion put paid to Natal history (including the rebellion) as a discrete and viable subject, and it, too, is practically forgotten, too. Third, Stuart having dealt with the military and Marks with the politico-economic aspects in such detail, there is little incentive for scholars to go further. And fourth, if they do, they will find that the archival records are so extensive and varied (as Marks indicated), that to really get into them would require extraordinary patience and perseverance. Thus it seems unlikely that much more will be published, and, unfortunately, some useful in-depth studies of several phases and localities may never appear. This is the case with Nkandla. The

${ }^{10}$ Studia Missionalia Upsaliensia 78, distributed by the Swedish Institute of Missionary Research, Uppsala.

${ }^{11}$ All three were published by the University of KwaZulu-Natal Press.

${ }^{12}$ All three were published privately.

${ }^{13}$ See Shula Marks, "Class, ideology and the Bambatha rebellion," in Banditry Rebellion and Social Protest in Africa (edited by Donald Crummey; London, Curry, 1986), pp. 351-372; Robert King, "The Smythe Administration and the Zulu Rebellion of 1906," New Contree, 42 (1997), pp. 91-109; Michael Mahoney, "The Millennium comes to Mapumulo; Popular Christianity in Rural Natal, 1866-1906," Journal of Southern African Studies, 23, 3 (Sept. 1999), pp. 375-391; Sean Redding, "A Blood-Stained Tax: Poll Tax and the Bambatha Rebellion in South Africa," African Studies Review, 53, 2 (Sept. 2000), pp. 29-54; and P. S. Thompson, "Bambatha's Personal Rebellion," Natalia, 33 (2003), pp.59-66; "The Zulu Rebellion of 1906: The Collusion of Bambatha and Dinuzulu," International Journal of African Historical Studies, 36, 3 (2003), pp. 533-557;"Bambatha's Rebels: a profile - Age, Faction, Motive," Historia, 48, 2 (Nov. 2003), pp. 98-108; and "Bambatha after Mome: Dead or Alive?" Historia, 50, 1 (May 2005), pp. 23-48. 
rich archival sources on it have scarcely been tapped, and neither Stuart nor Marks have given a comprehensive or very clear picture of what went on there. It is the purpose of this article to partly fill the gap.

The Nkandla district became a crossroads of war when the petty chief Bhambatha of the Zondi tribe, who had begun the rebellion in Natal, found no support among neighbouring chiefs. His insurgent band was being surrounded by strong government forces, so he fled to Zululand. There he found much sympathy and, specifically, the active support of the important chief Sigananda, of the Chube tribe. Sigananda's stronghold was the Nkandla Forest.

The rebellion became a war in which the government militia and police, organized and equipped along contemporary European lines and assisted by levies of loyal Africans organized along traditional lines, were pitted against traditionally organized and primitively equipped native rebels. The rebels took refuge in the Nkandhla Division of Zululand, notable for its rugged terrain and some dense forests. They could sally from the bush to attack, then retire to it and elude pursuers. It took the government ten weeks to defeat the rebels. Strategic points were recognized and contested. The government wanted a pitched battle, in which superior training and technology would assure a victory. The rebels tried to avoid such a battle, and played a kind of hide-and-seek, taxing the patience and wearing down the government while soliciting greater popular support. Both sides sought to win over fence-sitters by propaganda, by appeals and by threats, and then by force. The militia and police could not wage war effectively without the active assistance of loyal chiefs and their followers - indeed, the native levies in the field outnumbered the rebels - however, loyalists and rebels were neighbours, and so the conflict became a civil war. When the territorial lines were drawn, the war became a contest for the resources on which the rebels depended for sustenance.

Thus the policies of politicians and practices of soldiers on both sides intersected with the daily lives and activities of the civilian population. The majority of noncombatants in the operational area were families of rebels; the minority were loyalists, for some tribes divided. Their experience at the crossroads of war was one of random deaths, burnt homesteads, destroyed crops and granaries, and livestock carried off. It is this experience which is the main focus of this paper.

\section{Nkandla and its people}

The Nkandla district is at the southwestern corner of Zululand. The Mzinyathi and Thukela Rivers are the southern boundary, and on the left bank the 
ground rises in broken hills and ridges to the Nkandla-Qudeni mountain range. In several of the southern clefts were primeval forests, collectively known as the Nkandla forest in the East and the Qudeni forest in the West. North of the mountain range is the Mhlatuze river, approximately parallelling the Mzinyathi-Thukela about twenty miles distant. The range broadens to a narrow plateau on the north side, but then the watershed becomes broken and there are no forests. The rivers mentioned are natural boundaries, but the eastern and northwestern boundaries of the Nkandhla magisterial division are artificial, set arbitrarily after Zululand was annexed by the British in 1887 and became part of Natal in $1897 .^{14}$

The seat of the magistracy was centrally located, on the eastern slope of Mpandla hill and the settlement was appropriately named Empandhleni. In 1905 the white population of the Nkandhla Division was estimated at just 145 persons. There were one mine and two saw mills, eleven or twelve trading stores, and seven mission stations in the division. In 190672888 acres on the Qudeni range had been opened to European settlement, but only fifteen of the forty-one lots had been taken up. The district was not easily accessible. The few roads were little more than tracks. There were no bridges. ${ }^{15}$

The people of the Nkandla were Zulu, but only in the sense of having been subjects of the short-lived Zulu kingdom, established in the early nineteenth century. In 1906 fourteen chiefs and sixteen tribes and portions of tribes resided in the Nkandhla Division. ${ }^{16}$ The colonial government preferred to recognize hereditary chiefs of historic tribes as part of a system of indirect rule; however, it could make changes for ease of administration and control. Chiefs owed their position and gave their allegiance to the Supreme Chief, the Governor of the Colony of Natal,

${ }^{14}$ Zulu orthography has changed over the years. For official place names I use the 1906 spellings, but otherwise I use the current spellings for names, e.g. the Nkandhla Division, but the Nkandla forest.

${ }^{15}$ Colony of Natal, Statistical Year Book for the Year 1905 (Pietermaritzburg, Davis, 1906; hereafter cited as $S Y B$ ), pp. 12, 77, 82-83 and 118-119, and for the Year 1906, pp. 75 and 77. See also the maps in Zululand Delimitation Commission 1902-1904, Report by the Joint Imperial and Colonial Commissioners (Pietermaritzburg, Davis, 1905); and the loose maps showing the area, M4/109 (no title, 1903), 2/88 (Nkandhla District, 1906), and III/4/37 (Field Intelligence Department-Army Head Quarters, 1901), all in the map collection of the Pietermaritzburg Archives Repository.

${ }^{16}$ See the accompanying map and the appendix for the various tribes and their location. 
representing the British Crown. To pay for the administration the government levied a hut tax of $14 s .{ }^{17}$

The largest of the tribes, the Chube (or Shezi), was a linguistic sub-group which antedated the Zulu kingdom and had adhered to it without having been conquered. During the Usuthu rebellion of 1888, the chief Sigananda had been an unswerving supporter of the young Zulu king Dinuzulu. The old chief had been an ardent supporter of the Zulu monarchy, and the last king, Cetshwayo, had found sanctuary with him at the end of the Zulu civil war, in 1884. One of Sigananda's headmen was caretaker of Cetshwayo's grave, close by the chief's major homestead. ${ }^{18}$ The Magwaza and Ntuli tribes had also been Usuthu partisans. Dinuzulu had been defeated, deposed and exiled, and after ten years had returned, but as a chief only, of the Usuthu tribe in the Ndwandwe Division. None the less many Zulu still regarded him as their king. ${ }^{19}$

The African population was estimated at 27664 in 1905 . They were a traditional society engaged in subsistence agriculture, in which cattle were the principal measure of wealth and the medium of exchange. The chief crops were maize and sorghum, eked out with pumpkins, sweet potatoes and other garden

${ }^{17}$ See the sources cited in n. 1, and also A. T. Bryant, Olden Times in Zululand and Natal containing earlier political history of the Eastern-Nguni clans (London, Longmans, Green, 1929), pp. 58-60, 127, 259-261 and 415-416, and John Wright and Carolyn Hamilton, "Traditions and transformations: The Phongolo-Mzimkhulu region in the late eighteenth and early nineteenth centuries," chapter 3 in Natal and Zululand from earliest times to 1910: a new history (edited by Andrew Duminy and Bill Guest; Pietermaritzburg, University of Natal Press and Shuter \& Shooter, 1989), especially pp. 50-57. For colonial policy and practice with regard to the native population, see Lambert, Betrayed Trust, and David Welsh, The Roots of Segregation: Native Policy in Colonial Natal, 1845-1910 (Cape Town, Oxford University Press,1971). Stuart states (p. 204) that the name Nkandhla derives from the verb meaning to tire, exhaust or prostrate, although the 1905 Colenso dictionary gives the meaning to oppress, as by enforcing excessive labour.

${ }^{18}$ See Stuart, pp. 188-211, and P. S. Thompson, Bambatha at Mpanza: The Making of a Rebel (Pietermaritzburg, private, 2004), chapters 7-9.

${ }^{19}$ See John Laband and Paul Thompson, "The reduction of Zululand, 1878-1904," chapter 8 in Natal and Zululand from earliest times to 1910; Stuart, pp. 209-210; and more particularly John Laband, The Atlas of the Later Zulu Wars 1883-1888 (Pietermaritzburg, University of Natal Press, 2001), pp. 65-68, 73, 76 and 104. Stuart focuses on the amaChube and Sigananda, pp. 207-210. 
vegetables. The resident magistrate reported that the division had a good harvest in 1905 and there was an abundance of food. ${ }^{20}$

Which does not mean that life was a traditional idyll. The magistrate reported that 656 identification passes had been issued and 390 renewed, indicating service being taken in the Colony outside the division, and 727 passes had been issued for service outside the Colony, chiefly in Johannesburg. Presumably the overwhelming majority of these passes were for males, who were reckoned at 11 778. The 1904 census had given 10852 males, of whom 5338 were over fifteen. It would thus appear that one-third of the male adults were work-seekers away from home for some period of time. The magistrate expressed his concern, for "there can be no doubt that, in large labour centres, such as Durban, Pietermaritzburg, and Johannesburg, the Natives acquire most of their vices and lose their self-respect." ${ }^{21}$

The colonial records contain nothing to indicate that such unwholesome contacts contributed directly to resistance to the colonial regime in Nkandla. Much has been written about the competition between the increasing numbers of settlers

20 See $S Y B$, p.13 (population) and pp. $92-93$ (crops). The 1905 estimates are for maize 16406 muids (on 9032 acres), sorghum ("kafir corn") 11229 muids (on 6775 acres), pumpkins 749 tons (on 380 acres), sweet potatoes 400 muids (on 100 acres) and tobacco $20000 \mathrm{lbs}$ (on 200 acres). "The muid is an uncertain measure, but in Natal is generally considered to contain $200 \mathrm{lbs}$. of grain other than oats, $180 \mathrm{lbs}$. of oats, and 150 lbs. potatoes." (SYB 1909, pp. 108n and 109n) SYB gives (p. 101) 27 656 cattle, 23030 unwoolled ("kafir") sheep, 41068 goats, 1723 pigs, and 628 horses; however, the magistrate, in his report (Colony of Natal, Department of Native Affairs, Annual Reports for the Year 1905 (Pietermaritzburg, Times, 1906; hereafter cited as $A R)$, p. 87), estimated for the same year 12000 cattle, 13250 unwoolled sheep and 300 woolled sheep, 40000 goats, 700 pigs, 900 horses, and 54 000 poultry! His mention of the good harvest (p. 86) fits in with the remarks of Stuart (p. 202) about "the healthiest and most fertile" district and Bosman (p. 109) on the "peace and plenty" in Sigananda's ward and the comments of the Commissioner for Native Affairs' political agent's with the Fort Yolland column on the fertility of the Nkunzana valley, in Sigananda's ward (R. H. Addison to the CNA, May 31, 1906, confidential minute C142/1906 in the records of the Prime Minister (hereafter cited as PM). Yet the CNA referred to Sigananda and his son and heir Ndabaningi as "practically paupers"! (PM 59: 466/06, CNA to PM, April 28, 1906.) All documents cited are in the Pietermaritzburg Archives Depot, and, except in the first instance, a records group is cited, shall be referred to by records group, volume, document assignment, correspondents and date. Detailed statements of African agricultural production do not appear in later $S Y B$ s or $A R \mathrm{~s}$.

${ }^{21}$ AR 1905, pp. 87-88. See also Census of the Colony of Natal April 1904 (Pietermaritzburg, Davis, 1905), p. 287. 
and natives for resources, especially arable land, and the settlers' near-monopoly of power to secure their advantages, both in Natal and in South Africa during this period; ${ }^{22}$ however, there is little - a somewhat less-than-spontaneous Chube demonstration against the collection of the poll tax, ${ }^{23}$ and some native expressions of resentment against alienation to settlers of the lots on the Qudeni ${ }^{24}$ - to suggest an economic impetus to rebellion in the district. If anything, the impetus was political, and depended on the Usuthu connexion. ${ }^{25}$ It is unlikely, pace Bhambatha, that there would have been a rebellion had it not been for Dinuzulu.

During the latter part of the South African War the British called into service a small Zulu force under the aegis of Dinuzulu, which had shown its mettle in an encounter with a small Boer commando. In the unsettled postwar period, marked by disappointed expectations and economic depression, the people in Zululand and Natal were agitated by rumours of a change for the better and without the whites, often enough under the lead of Dinuzulu, and it would have been surprising if there had not been a rekindling of Usuthu ambitions. ${ }^{26}$

${ }^{22}$ See, e.g. just for Natal, Marks, parts I-III; Lambert, chapters 5-10; Carton, chapter 2; Ruth Edgecombe and Bill Guest, "An introduction to the pre-Union Natal coal industry," in Enterprise and Exploitation in a Victorian Colony: Aspects of the Economic and Social History of Colonial Natal (edited by Bill Guest and John M. Sellers; Pietermaritzburg, University of Natal Press, 1985), pp. 309-351; Bill Guest, "The new economy" and Andre Duminy and Bill Guest, "The Anglo-Boer War and its economic aftermath," chapters 12 and 14, respectively, in Natal and Zululand from earliest times to 1910; John Lambert and Robert Morrell, "Domination and Subordination in Natal 1890-1920," Chapter 3 in Political Economy and identities in KwaZulu-Natal: Historical and Social Perspectives (edited by Robert Morrell; Durban, Indicator Press, 1996), and, of course, Colony of Natal, Report of Native Affairs Commission 1906-7 and Evidence (Pietermaritzburg, Davis, both 1907).

${ }^{23}$ See Colenbrander, pp. 11-12; 1/NKA 1/5/1/1: Criminal Note Book (Martial Law), No. 3, Rex v.Nzazana et al., and PM 59: 463/06, Mgt Nkandhla to CNA, January 24, 1906.

${ }^{24}$ See and cf. SYB 1906, pp.75, 77, 110, and Colony of Natal, Native Affairs Commission 1906-7, Evidence (Pietermaritzburg, Davis, 1907; hereafter cited as NAC), p. 133.

${ }^{25}$ See above, pp. 3-4 and 5, and cf. Marks, chapter 4.

${ }^{26}$ See John Laband, "Zulus and the War," in The Boer War: Direction, Experience and Image (edited by John Gooch; London, Frank Cass, 2000), pp. 107-125, and Peter Warwick, Black People and the South African War 1899-1902 (Johannesburg, Ravan, 1983), Chapter 4. Marks, Chapter 6. AR, pp. 106-107. NAC, pp. 132-134. C. T. Binns, Dinuzulu: The Death of the House of Shaka (London, Longmans, 1968), Chapter 12. 
A combination of circumstances made the Nkandla an ideal place in which to nurture and to promote rebellion in 1906. The Commissioner for Native Affairs in Zululand was quoted telling an investigating commission afterwards:

... The people at Nkandhla doubtless had the feeling that by reason of the ruggedness of their district they were unassailable, but they were also very bitter there on account of the land being taken away from them. The Nkandhla had always been one of the most rebellious districts in the country, and he did think Bambata would have got a footing in any other part of Zululand. ${ }^{27}$

\section{Contest for hearts and minds - and position}

The colonial government's chief official in Zululand, the Commissioner for Native Affairs, Charles Saunders, went to the Nkandhla magistracy immediately after Bhambatha and his band arrived in the division. The resident magistrate, Benjamin Colenbrander, ordered the chiefs through whose wards Bhambatha might pass to arm their men to intercept and deliver him over. Bhambatha was too quick for them. He passed into Sigananda's ward and hid in the forest. The commissioner repeatedly directed the ninety-six-year-old chief to capture the rebel chieftain, and warned of the consequences of his not doing so. Sigananda procrastinated and dissembled for a week. Then he presented Bhambatha to his own and other tribes as the man sent by Dinuzulu to start a rebellion. The rebels deliberately built their war huts next to the grave of the last Zulu king Cetshwayo. Sigananda and sympathetic headmen also used Bhambatha to promote rebellion in surrounding areas. They branded those loyal to the government "traitors", because they were disloyal to Dinuzulu, and warned them to "plait a long rope with which to climb up to the heavens" to escape his wrath. Most of the Magwaza and Ntuli tribes rebelled, but without their chiefs. Rebels raided other tribes which did not, which as often as not frightened away the tribesmen and antagonized their chiefs. ${ }^{28}$

27 NAC, p. 133.

${ }^{28}$ See Colenbrander, pp. 15-17; Stuart, chapters 8 and 9; OD, pp. 97-101: CNA to PM, Apr. 28, 1906; and cf. Guy, pp. 94-96. See also the daily communications of the CNA to the PM and Commandant of Militia in the records of the Colonial Secretary's Office (hereafter cited as CSO), volumes 3039 and 3040. On “plaiting a rope" see Colenbrander, pp. 17 and. 26; declaration of Mangati, Dec. 18, 1907, in the records of the Governor of Natal (hereafter cited as GH) 1462 and also of the Secretary for Native Affairs (hereafter cited as SNA) I/6/29; evidence of Mpikwa in Rex v. Mjado, in the records of the Nkandhla Magistrate (hereafter cited as $1 / \mathrm{NKA}$ ) 1/5/1/1, no. 7; statement of Yena in the court martial of Jikajika et al. in SNA I/6/26: GH 285/06; statement of Macala, in Rex v. Macala (1/NKA 1/5/1/2, no. 61); "Rex 
The officials at Empandhleni fortified themselves in the magistracy against a coup de main by the rebels, and did not feel safe until the arrival of the Zululand Mounted Rifles (on the $9^{\text {th }}$ ) and the Natal Police field force (on the $12^{\text {th }}$ ), after which Empandhleni became the base of government operations in the division. Meanwhile the government mobilized militia and dispatched the Natal Carbineers under Colonel D. W. Mackay with a convoy of supplies and ammunition to Empandhleni. They arrived on April $25^{\text {th }}$, and the police field force and mounted rifles were posted to Fort Yolland and Ntingwe, respectively, to prevent the spread of the rebellion in those quarters. Across the Thukela, an Umvoti Field Force guarded against a rebel irruption into Natal. ${ }^{29}$ Bhambatha and Mangathi, the leader of the rebels among the amaNtuli, may have contemplated an attack on the magistracy, but Sigananda would not have it. They were all agreed on a basic defensive strategy: keep to the forest, entice the enemy in and ambush him in small groups. Under no circumstances attack the enemy's camps or fortified places. ${ }^{30} \mathrm{By}$ the end of April government forces had more or less contained the rebels in the southern part of the Nkandhla Division.

If Dinuzulu had boldly put himself at the head of the rebels, there probably would have been a largescale uprising; but he did not. He said publicly that he was loyal to the government, and offered to send an army of his followers to the Nkandla to assist in the capture of Bhambatha. The commissioner did not distrust Dinuzulu, but he would not trust his army in the volatile Nkandla. He got him to send his trusted headman Mankulumana to tell Sigananda that he had not instigated the rebellion and to desist from it and to arrange for the capture of Bhambatha.

versus Cakijana-ka-Gezindaka: Resume of statement made by Cakijana at Krantzkop, on the $20^{\text {th }}$ May 1908" (hereafter cited as Resume), referring to Mangathi, in the records of the Attorney General (hereafter cited as AGO). On "traitors" see Colenbrander, p. 17; particularly those among the amaChube, see statements of Msinda, in SNAI/6/26: GH 285/06, of Nsuze, in The James Stuart Archive of recorded oral evidence relating to the history of the Zulu and neighbouring peoples (edited by $\mathrm{C}$. deB. Webb and J. B. Wright; 5v. Pietermaritzburg, University of Natal Press, 1976-2001; hereafter cited as JSA), V, 157, and of Umbambela [Apr. 1906] in 1/NKA 3/2/1/1; and the evidence of Ngidi, in Rex v. Ndabaningi in SNA I/6/26.

${ }^{29}$ See Colenbrander, pp. 15 and 18; Stuart, pp. 189-190, 216-218; and HAZR, pp. $18-21$.

${ }^{30}$ Stuart, p. 202. GH 1465: reports of Intelligence Krantzkop May 4 (p. 125) and OCUFF, May 6, 1906 (p. 130). R. v. Sigananda: Mgoqo and Polomba. 1/NKA 1/5/1/2, no. 43, R. v. Bekuzulu: Mbambela. JSA V, 179: Nsuze. 
Mankulumana told the commissioner that he was prevented from meeting Sigananda, but had conveyed the desired message to his son and other leading rebels. We cannot be sure just what he said, but in any event it was obvious to all that Dinuzulu was not coming with a force to support the rebels. ${ }^{31}$

The rebels were at an impasse. Dinuzulu had let them down, at least for the moment. Without him they had no unity of command. Bhambatha was not an important chief in Natal, and he had no influence as a fugitive in Zululand. Sigananda had much influence, and evidently he was alert mentally, but he had lost his physical strength. It is difficult to determine what power his son and heir Ndabaningi had. It is not clear whether the rebel leaders consulted among themselves or held councils of war. The one singularly energetic leader among the rebel headmen was Mangathi, of the Ntuli tribe, who formed a separate unit and went his own way. ${ }^{32}$

${ }^{31}$ Stuart, pp. 213-216 and 487-494. Bosman, p. 106. PM 59: 463/06 and CSO 3040: CNA to PM, Apr. 19 and 20, 1906. On Dinuzulu's offer and his headman Mankulumana's mission, see Stuart, pp. 214-217, and $O D$, pp. 76-78; and the evidence in R. v. Sigandanda (two slightly different versions of the trial, in Colenso Collection (PAR A204), 126, and Bosman) of Mgoqo; and in R. v. Dinuzulu, in the records of the Registrars of the Supreme Court (hereafter cited as RSC) III/3, pp. 1552-1554, 1813-1815 (Cakijana), 2639-2664 (Langalibomvu), 2783-2784, 27892792, 2832-2834, 2836, 2861-2862 (Mangati), 3477 and 3480 (Colenbrander), 3533-3540 (Armstrong), $4052 \quad$ (Dinuzulu), 4702-4705, 4711/12-4717 (Mankulumana), 5120 (Dulela), 5195-5199 (Nopungwa), 5224-5226 (Godi); and the statements of Mankulumana, Apr. 27, 1906, in AGO I/7/68 and PM 59: 465/06, and of Ngoqo, Apr. 6, 1908, in AGO I/7/54 and 70. Hereafter, in citations of trials, the names of defendants making statements and of witnesses giving evidence will simply be given. See also GH 1465, pp. 85 and 87 (Commandant to Governor, Apr. 15 and 20, 1906), 93 (Mgt Nongoma to PM, Apr. 18, 1906), 98 (CNA to PM, Apr. 19, and Chief Commissioner of Police to PM, Apr. 20, 1906); CSO 3040: CNA to PM (Apr. 20, 1906); SNA I/1/343: 1856/06: Notes of Interview between the Governor and Dinuzulu's envoys (June 20, 1906): Mankulamana's statement.

${ }^{32}$ R. v. Dinuzulu, pp. 2667-2671: Langalibomvu. RSC III/3, R. v. Cakijana, p. 249: Ndabazezwe. R. v. Sigananda: Mgoqo, Mpikwa, Ndabaningi, Polomba, Simoyi. R. v. Tulwana, R25/07, in the Zululand Archives (hereafter cited as ZA): Ndabaningi. PM 102: C230/06, Officer Commanding, Umvoti Field Force [Col. Leuchars] to [Minister of] Defence, May 6, 1906. For Sigananda's quickness (and perversity) of mind, see Bosman, pp.108-110, and Stuart, pp. 400-401. Mangathi's independence becomes clear from the study of operations. 
The commissioner estimated on April $16^{\text {th }}$ that the rebel army numbered between 700 and 1000 men in twelve to fourteen companies. ${ }^{33}$ Apparently an attempt - scarcely surprising with partisans of the Usuthu - was made to organize at least the Chube component by regiments, i.e. the age sets embodied originally for labour and war by the Zulu kings, but since their time fallen into destitude. ${ }^{34}$ It is not clear whether or not an effort was made to do so among the other tribal units. ${ }^{35}$ Towards the end of period a mounted unit was organized, apparently equipped with firearms, but it does not seem to have had any tactical role - it is mentioned herding looted cattle. ${ }^{36}$

Equipment and training were equally primitive. The great majority of men were armed with spears and shields, and the very few who had firearms did not know how to use them properly (in a military sense), except for sniping, but even then most were poor shots. ${ }^{37}$ Tactics were as unimaginative as strategy. The rebels knew of and used the traditional Zulu offensive formation - horns, chest, loins - in action at Mpukunyoni and possibly at Bobe and Manzipambana (and one may speculate about the actions at Dlolwana and Msukane). ${ }^{38}$

At least morale was high - at the beginning. On the higher plane they had a just cause and were fighting for the old order and the Zulu monarchy. All wore the

33 OD, p. 101: CNA to PM, Apr. 28, 1906. See also CSO 3040: CNA to PM, Apr. 17, 1906; GH 1465, p. 93: CNA to PM, Apr. 19, and CCP to PM, Apr. 20, 1906.

${ }^{34}$ See Stuart, ch. 4; R. v. Sigananda: Polomba, and SNA I/6/27: GH 275/06, Umgoqo.

35 SNA I/6/27: M.J. C194/06, R. v. Mkamangana et al.: Magodongwana. R. v. Cakijana, p. 128: Bova.

${ }^{36}$ PM 101: C156/06, R. H. Addison to CNA, June 11, 1906. R. v. Cakijana, pp. 349350: Cakijana. Resume. GH 1466, p. 57: report by Intelligence, Zululand Field Force, June 7, 1906.

37 That the rebels were armed with spears and shields is evident throughout the accounts, but may be confirmed specifically in this case by SNA I/6/26: GH 285/06, Qibiti and I/6/27: MJC194/06, Mqayikana. On firearms and shooting, see Stuart, pp. 235, 239, 273, 292; CSO 3040: Officer Commanding, Zululand Field Force, to Defence, May 15, 1906; GH 1466, p. 62: id. to PM, June 7, 1906; PM 101: C156/06, Addison to CNA, June 11, 1906.

${ }^{38}$ See and cf. Guy, pp. 88-89; Laband, pp. 4-8; Stuart, pp. 412-413; and HAZR, p. 4. At Manzipambana it seems that the militia under attack were under the impression the rebels were using the horns formation (see Stuart, pp. 287 and 292), but the account of the battle does not confirm that impression. 


\section{8}

traditional white cow tail badge, and cried "Usuthu!" when they went into battle. ${ }^{39}$ Their headquarters and main camp were next to Cetshwayo's grave. ${ }^{40}$ Of course, when Dinuzulu denounced them publicly a good number of rebels and rebel sympathizers thought twice, but by then most were committed and afraid to quit. ${ }^{41}$ And they believed - at the beginning - that they were invulnerable to the white man's bullets. Bhambatha had them doctored with special medicine so the bullets would not penetrate their bodies. ${ }^{42}$

The rebel deficiencies became manifest at the battle of Bobe on May $5^{\text {th }}$, a chance encounter with a police/militia reconnaissance party out of Fort Yolland. Sigananda's men attacked in the open and found that the white men's bullets indeed penetrated. In one determined charge the attackers lost about sixty killed and fled. Bhambatha's men, moving on one flank through thick bush, then retreated without fighting and without loss. ${ }^{43}$ There were bitter recriminations between the two

39 On the battle cry "Usuthu!" see Stuart, pp. 231, 252, 271 and 287. On the adoption of the Usuthu tshokobezi badge, see Stuart, p. 198; JSA V, 165, 176: Nsuze; R. v. Ndabaningi: Ndukuyezulu, Nkunya, Polomba; R. v. Dinuzulu, p. 1712: Cakijana; 1/NKA 3/2/1/1: statements of Masotsha, Apr. 25/26, 1906, and 1/5/1/2, no. 46: Maqoqwana; and SNA I/1/26: GH 285/06, Ndhlekeza and Qibiti.

${ }^{40}$ Colenbrander, p. 17. Stuart, p. 202.

41 See and cf. Stuart, p. 202; R. v. Dinuzulu, pp. 1529-1532: Cakijana; R.v. Cakijana, p. 241: Ndabazezwe; R. v. Sigananda: Dunga, Mgoqo; R. v. Ndabaningi: Ngidi; and SNA I/6/27: MJC 194/06, Ubuso. On the youthfulness of the rebels see GH 1465, p. 91: CNA to PM, Apr. 17, 1906; CSO 2599: C147/06, Diary of the Umvoti Field Force (hereafter cited as UFF Diary), Apr. 19, 1906; PM 101: C156/06: Addison to CNA, June 11, 1906; and SNA I/1/345: 2306/06, Mgt Nkandhla's report in reply to SNA Circular 11/06; and on their bellicosity, UFF Diary, Apr. 29, 1906, and CSO 3040 and PM 102: 228/06, CNA to PM, June 4, 1906.

${ }^{42}$ Colenbrander, p. 17; JSA, III, 320: Mputshana, and V, 178-179: Nsuze, on which is based Stuart, 199-202. R. v. Cakijana, pp. 125-126: Bova. OD, p. 101: CNA to PM, Apr. 28, 1906. GH 1465, p. 112: OCUFF to PM, Apr. 26, 1906. SNA I/6/27: GH 292/06, R. v. Fogoti et al: Qusibindi. R. v. Nqakamatshe and Mcitsho: Mcitsho, in the records of the Magistrate of Weenen, 1/WEN 1/4/2/1, no. 20.

${ }^{43}$ For narrative accounts of the battle see Bosman, pp. 31-33; Stuart, pp. 230-236; $H A Z R$, pp. 22-23; and the reports of Col. Mansel, May 6, in CSO 3040, and Maj. Campbell, May 8, 1906, in PM 102: C230/06. For details on the rebel side see JSA V, 178-179: Nsuze; Resume; R. v. Dinuzulu, pp. 1545-1546, 1827-1829; Cakijana; R. v. Cakijana, p. 140: Baletshe, and also the MS of the trial in AGO I/7/58: Bova; GH 1462 and SNA I/6/29, statement of Mangati, Dec. 18, 1907; R. v. Nqakamatshe: Mcitsho; SNA I/6/27: GH 275/06: Dunga, and MJC 194/06: Mpetempete, Nogalaju, Sikakula; AGO I/7/80, statement of Msolwa, Apr. 4, 1908. Cf. Zungu, p. 18. 
groups. Bhambatha left them and joined Mangathi at Macala hill. ${ }^{44}$ Demoralization and desertion were the consequences. ${ }^{45}$ And still no sign of Dinuzulu. Sigananda reported the defeat to him and apparently received a reprimand for bad tactics. ${ }^{46}$

The Zululand Field Force, under Colonel Sir Duncan McKenzie, arrived with another convoy at Empandhleni on May $8^{\text {th }}$. The Carbineers were relieved and sent back to Natal with the empty wagons. McKenzie moved camp to the edge of the forest and examined the terrain. He proposed to take the offensive, and called on loyal chiefs to furnish levies to accompany the militia. Neutrality was no longer an option for the Nkandla tribes.

McKenzie moved against the rebels at Cetshwayo's grave on May $17^{\text {th }}$. He took them by surprise. Mangathi's men attacked one column at Msukane, but were driven off. The other rebel forces offered no resistance. The three government columns met at the grave and bivouacked. Levies burnt the war huts (and accidentally some brush near the grave - which Sigananda described as though it were a provocation in a message to Dinuzulu), collected cattle, and destroyed crops. Next McKenzie moved against Sigananda's stronghold in the Mhome gorge. ${ }^{47}$

${ }^{44} O D$, p. 133: CNA to PM, May 26, 1906. GH 1462 (and SNA I/6/29): Mangati, Dec. 18, 1907, and 1465, reports of CCP, May 9 (p. 138) and of OCUFF, (May 11, 1906 (p. 80 [sic]). 1/NKA 1/5/1/1, no. 11: R. v. Nteleki et al: Nteleki. JSA, II, 178179: Mangati, and V, 178-179: Nsuze. SNA I/ 6/27: MJC 194/06: Sofuguza. R. v. Sigananda: Mgoqo, Ndabaningi, Polomba.

${ }^{45}$ Colenbrander, pp. 19-20. $O D$, p. 133: CNA to PM, May 26, 1906. GH 1465, reports of CNA, May 6 (p. 133), CPP, May 9 (p. 138), and OCUFF, May 12 (p. 80[sic]). R. v. Ndabaningi: Polomba. R. v. Sigananda: Mgoqo. SNA I/6/27: MJC 194/06: Sofuguza. 1/ NKA 1/5/1/1, no. 10: R. v. Ncacana et al.: Nomapa, and 1/5/1/2, no. 43:R. v. Bekuzulu: Mandisindaba. AGO I/7/55: Transcript of notes taken at an interview between J. S. Hedges and Ndabaningi and Lunyana, Feb. 14, 1907.

${ }^{46}$ R. v. Sigananda: Mgoqo, Ndabaningi, Polomba.

${ }^{47}$ Bosman, pp. 34-46. Stuart, pp. 236-244. Colenbrander, pp. 20-22. HAZR, pp. 24-25. W. J. Powell, The Zulu Rebellion of 1906: A Souvenir of the Transvaal Mounted Rifles (Johannesburg, Transvaal Leader, 1906), pp. 29-31. CSO 2599: C147/06: General Report by Sir D. McKenzie, 28.4.06 to 2.8.06 (hereafter cited as McKenzie's Report). UFF Diary, May 15, 1906. CSO 3040 and PM 102: C230/06: OCZFF to Defence, May 18, 1906. OD, p. 138: Mgt Nkandhla to CNA, May 26, 1906. Resume. PM 104: C238/07, Mangati, Nov. 23, 1907. 1/NKA 1/5/1/1, no. 24 : R. v. Mkakwa et al:: Mpumela. 
At this moment Sigananda and Ndabaningi sent emissaries, proposing to surrender - but it would take time to consult the headmen and to collect the people and then to surrender at Empandhleni, not at Mhome. McKenzie was skeptical but patient, and he agreed to a truce and gave them a week to come in. He left a force at the grave, and marched the main column back to the magistracy. The rebels threatened and sniped at the rear guard, provoking a counter fire. There was no surrender. McKenzie and Saunders chalked it up to the old man's deceitfulness. ${ }^{48}$

\section{War on resources}

The rebel army lived off the land. They had no depots. The people in the neighbourhood provided food and drink from their homesteads - the produce of their gardens and fields and the stores of their grain pits. ${ }^{49}$ Stock would be slaughtered as necessary. ${ }^{50}$ When the men were on the move, they carried some food with them, ${ }^{51}$ and, when they could, looted loyalists' homesteads and herds and the white men's stores. ${ }^{52}$ Sometimes they had to move about just to get food, ${ }^{53}$ and some individuals went home to be fed. ${ }^{54}$

In late April and early May the Natal Carbineers had "cleared" the area around the magistracy, ostensibly as a security measure, but Mackay also proposed to undercut the rebels by destroying their shelters and supplies. ${ }^{55}$ For his part, McKenzie wrote to the Commandant of Militia on May $11^{\text {th: }}$ "It is absolutely impossible to starve these people out by sitting quietly on the hills and allowing

${ }^{48}$ Bosman, pp. 47-52. Powell, p. 33. Stuart, pp. 245-249. Colenbrander, pp. 22-23. R. v. Sigananda: Mgoqo. GH 1466, p. 39: report of Intelligence Krantzkop, May 31, 1906.

${ }^{49}$ Colenbrander, p. 17. McKenzie's Report. UFF Diary, May 27, 1906. GH 1466, p. 53: report of OCZFF, June 6, 1906. Powell, p. 32. Stuart, p. 247. JSA, V, 174, 177: Nsuze. SNA I/6/27: GH 275/06, Mbumbula.

${ }^{50}$ Resume. SNA I/6/27: GH 275/06, Umgoqo. R. v. Sigananda: Ndabaningi.

51 JSA, V, 174: Nsuze. SNA I/4//16: C205/06, Addison to CNA June 15, 1906. SNA I/6/26: GH 285/06, Qibiti, and 27: MJC 194/06, Ubuso. See also Zungu, p. 30. 52 GH 1462 and SNA I/6/29: Mangati, Dec. 18, 1907. GH 1466, p. 14: reports of Intelligence Krantzkop, May 27 [and 28], 1906. R. v. Sigananda: Ndabaningi, Nongatsheni, Polomba. Stuart, p. 203.

53 JSA V, 177: Nsuze.

${ }^{54}$ SNA I/6/27: GH 275/06, Dunga.

${ }^{55}$ GH 1465, p. 120: Mackay to Defence, Apr. 30, 1906, and p. 134: reports of Mackay, May 7, and OCZFF, May 8, 1906. Stuart, p. 37. 
them to collect provisions everywhere at night, therefore it is absolutely necessary to operate against them and destroy all kraals and provisions. ${ }^{, 56}$

McKenzie's first "clearing" operations were along the fringes of the forest and near Ntingwe. Levies were used extensively. The Umvoti Field Force carried out similar sweeps along the left bank of the Thukela. The effect of these operations was noticeable almost at once. ${ }^{57}$ The commissioner reported that a good many women and children, some of considerable importance, surrendered at Empandhleni on May $15^{\text {th }}$, and with McKenzie's concurrence were sent to the homesteads of loyalist relatives. ${ }^{58}$ Another lot, men and women, were caught fleeing towards Sibudeni by the Fort Yolland column as it advanced, burning homesteads and seizing stock on May $16^{\text {th }} .59$

Then came the convergence on the grave. "The valley was black with horses and captured stock which were denuding the cornfields of all crops on which Sigananda and his leaders depended for the maintenance or their army." ${ }^{60}$ Homesteads were burnt and grain stores destroyed. About 800 cattle and 1500 goats were captured. ${ }^{61}$ Meanwhile the Umvoti Field Force, operating a few miles to the West, also destroyed homesteads and captured about 150 cattle and 600 goats. ${ }^{62}$

The intelligence officer with the Fort Yolland column told McKenzie: "You have given Sigananda a very severe knock. He has never had such an experience as to have lost such a number of cattle. He never reckoned on the invasion of the Insuzi Vally by your troops." The officer pointed towards Bobe ridge: "That was where Sigananda surrendered to the late Sir Melmoth Osborn in the eighties. He then had suffered no loss to be compared with this." McKenzie replied:

${ }^{56}$ GH 1465, p. 141: OCZFF to Defence, May 11, 1906. For justification of the policy, see Stuart, pp. 239-240, and Powell, pp. 28-29.

${ }^{57}$ Colenbrander, pp. 20-21. UFF Diary, May 13, 15, 18-19, 1906. GH 1465: reports of CNA, May 6 (p. 133), and of OCZFF, May 12 (p. 145), 15 (pp. 147 and 148) and 16 (p. 148), and of Intelligence Krantzkop, May 15, 1906 (p. 148).

${ }^{58}$ GH 1466 and PM 102: C228/06: CNA to PM, May 25, 1906. CSO 3040: Notes from telegraph messages between CNA and Commandant Militia, May 16, 1906.

${ }^{59} \mathrm{GH}$ 1465, p. 149: CCP to OCZFF, May 16, 1906. ZA 28: Addison to CNA, May 20, 1906.

${ }^{60}$ Bosman, pp. 44-45.

${ }^{61}$ GH 1465, p. 152: report of OCZFF, May 18, 1906. CSO 3040 and PM 102: C230/06: OCZFF to Defence, May 18, 1906. McKenzie's Report.

${ }^{62}$ Colenbrander, pp. 21-22. GH 1465: reports of OCUFF, May. 18, 1906 (pp. 150 and 152). UFF Diary, May 16-17, 1906. 
"I cannot look upon this as a severe knock at all. I hope to warm him up much more than this.",63

McKenzie now took a hard line on women and children. On the $18^{\text {th }}$ about two hundred of them came out of the forest, waving white flags. He would not let them surrender, and ordered them back into the forest. They did not appear to be malnourished. He would not allow them into his lines unless they were accompanied by their menfolk, i.e. the rebels must surrender, and not unload their dependants on the government for safekeeping. ${ }^{64}$

Again the effects were soon noticeable. Deserters from the rebel army were caught at the Thukela on May $25^{\text {th }}$ going back home to the Mapumulo Division: they said they had left because of a lack of food in the camps. ${ }^{65}$ One of Sigananda's headmen who lived near Ntingwe abandoned the rebel cause on May $28^{\text {th }}$ and brought his followers over to the government side. ${ }^{66}$

Then came the drives. The Commandant of Militia, Colonel Bru-deWold, sketched the procedure to McKenzie on the $28^{\text {th }}$ :

You should dismount sufficient men for bush operations, retaining enough mounted men only for engaging the enemy when they break cover. My idea is that the bush should be driven by [a] composite force of whites and blacks, in three lines. The first line in extended order, to consist of, say, a hundred picked men who volunteer for the work, each man to have under his control six natives, three on each side of him, and the whole forming the advance line of beaters. They will frequently halt and adjust their general alignment by sound of bugles. The second line of supports within close striking distance of the advanced line to consist, say, of twenty-five picked men each with a group of thirty natives. These men will be pushed forward to assist the advanced line as soon as the group commanders hear or learn that those in front have come into contact with, and are

${ }^{63}$ Bosman, p. 45.

${ }^{64}$ Colenrander, pp. 22-23. OD, pp. 139-140: Colenrander to CNA, May 26, 1906. ZA 28: Addison to CNA, May 20, 1906. See also Stuart, p. 247, and Powell, p. 32, and cf. Bosman, pp. 44-45.

${ }^{65} \mathrm{GH}$ 1466: reports of Mgt Mapumulo, May [25] (p. 10) and Intelligence Krantzkop [27] (p. 12). Militia to Mgt Eshowe, May 27, 1906, in the records of the Magistrate, Eshowe, 1/ESH 3/2/5.

${ }^{66}$ Colenbrander, p. 24. CSO 3040 and PM 102: C228/06, CNA to PM, June 1, 1906. R. v. Ndabaningi: Charles McKenzie. Stuart, p. 284. 


\section{3}

engaged with, the enemy. The third line to be reserves, each consisting of a group commander and thirty natives. ${ }^{67}$

In practice the disposition of men varied according to their number and the terrain, and McKenzie necessarily added a force as a backstop to the rebels, to gather them in. ${ }^{68}$

From May $29^{\text {th }}$ to June $7^{\text {th }}$ McKenzie drove the Nkandla forest, engaging small rebel forces in the Thathe gorge and at the Manzipambana stream and inflicting appreciable if not large losses. The Zululand Field Force killed perhaps 250 rebels and captured a thousand cattle and a large number of goats. ${ }^{69}$ It was reported that most of the rebel army in the Nkandla forest left for the Qudeni, and about half of those who had come from Natal deserted. ${ }^{70}$ On June $9^{\text {th }}$ McKenzie considered the Nkandla clear and prepared to move to the Qudeni and drive it. ${ }^{71}$

As might be expected, noncombatants and livestock were as likely to be caught in the drives as rebel soldiers. During the first few days of June the commissioner reported that large numbers of women and children flocked out of the forest in all directions. Some of them found refuge with relatives and friends in other tribes. $^{72}$ At the start of the drive at Mhome on June $1^{\text {st }}$ women and children were put on a hill out of the way until the drive was over, and then were sent back to the forest. ${ }^{73}$ There was no desire to detain them:

Native women were a source of much inconvenience throughout the campaign. They not only urged their menfolk to rebel and kept them supplied with food as well as they could, but taking advantage of the protection afforded their sex, frequently conveyed intelligence to the enemy as to the movements of the troops.

${ }^{67}$ OD, p. 129: Commandant to OCZFF, May 28, 1906.

${ }^{68}$ See Bosman, pp. 60-77 passim; Stuart, pp. 280-283, 285; HAZR, pp. 28-35;

${ }^{69}$ See and cf. McKenzie's Report; Bosman, pp. 61, 63, 67, 72; and Stuart, pp. 254, 255, 294-295.

${ }^{70}$ McKenzie's Report. GH 1466: reports of OCZFF, May 7 (p. 62) and Intelligence ZFF, May 9, 1906 (p. 66). Stuart, p. 314.

${ }^{71}$ McKenzie's Report.

${ }^{72}$ Colenbrander, p. 25. ZA 28: CNA to OCZFF, June 2, 1906. CSO 3040: Mgt Nkandhla to OCZFF, June 4, 1906. For noncombatants fleeing across the Thukela, see Bosman, p. 44; CSO 3040: Mgt Krantzkop to PM, May 16, 1906; GH 1466: reports of Intelligence Krantzkop, May [24] (p. 4) and 16, 1906 (p. 94).

${ }^{73}$ Bosman, p. 68. McKenzie's Report. OD, pp. 162-163: OCZFF to Militia, June 1, 1906. 
... Though it was conclusively proved that a good deal of the trouble was caused by the women, who goaded their husbands and relatives to rebellion, their sex secured for them protection by the troops. This the women only knew too well, and on frequent occasions availed themselves of their privilege, probably to the detriment of ourselves, as it was not only difficult but impossible to guard against female spies, who carried information of our movements to the enemy. ${ }^{74}$

The commissioner complained to the Prime Minister of the Colony about the way militia treated some loyal folk on the line of communication:

... I hope most strict and distinct instructions will be issued that loyal people and their property are not to be molested or interfered with in any way during the operations which may be conducted. Already loyalists have suffered considerably along the line of march of troops to this neighbourhood. This is of course inevitable with [the] movement of large numbers of men and animals and I am causing a record to be kept as far as possible of damage sustained but strongly urge that every precaution be taken in that direction. ${ }^{75}$

The magistrate was quite acid about the behaviour of the mercenary troops, in a report accompanying the submission of loss claims after the rebellion:

You will no doubt recollect the large number of Loyalists, particularly between this Magistracy and Owen's store, along the wagon road, who came in to complain that the Militia Columns particularly Col McKenzie's, which consisted of Royston's Horse, and the T.M.R. had looted, or allowed their stock to destroy their gardens, and in some instances individuals from these columns, as the evidence will show, deliberately went and looted property and robbed the kraals of their cash. These people all lodged their complaints at the time, and as you know we took steps to report it to the various O.Cs at the Magistracy, but owing to the Crisis, and state of chaos at the time, nothing could be done, excepting to register such claim, and inform the Claimants that the matter would be dealt with later. ${ }^{76}$

${ }^{74}$ The first quotation is from Stuart, p. 244, and the second from Bosman, p. 44. Stuart's single reference (p. 330) to "captive women" is puzzling.

${ }^{75}$ CSO 3040 and PM 102: C228/06: CNA to PM, May 26, 1906.

${ }^{76}$ SNA I/1/379: 2876/07, Mgt Nkandhla to CNA, Mar. 5, 1907. See below, p. 20. 
The absence of a further recorded complaint at this time suggests that the malpractice might have been corrected. It is counterproductive to plunder one's friends, and on both sides the policy was to spare noncombatants; however, they could get in the way unexpectedly, e.g. the commander of the Umvoti Field Force reported that in one sweep his men had fired at some rebels running across a corn field and unfortunately wounded a woman and child hidden in a corn hut. ${ }^{77}$

There was a fear among rebels - how widespread it is not possible to say that the levies would kill their people. During the truce the rebel emissaries sought and got the military's assurance that the levies would not harm women and children. ${ }^{78}$ The levies remaining with the troops at the grave did threaten to kill them if they came in, unless they could hold them to ransom. The authorities reflected and subsequently allowed the levies to ransom captives. The policy might be an added inducement to rebel soldiers to surrender. In many cases levies and captives were related by marriage. ${ }^{79}$

The levies from tribes on the periphery of operations also were concerned about the safety of their families. The rebels made a number of raids on exposed homesteads. They burnt them and took the livestock. Men might be killed or captured, but women and children apparently were not harmed. ${ }^{80}$ The magistrate

${ }^{77}$ UFF Diary, May 15, 1906. For reports of noncombatants being shot see 1/NKA 1/5/1/2, no. 61: R. v. Macala: Ganumfazi, and GH 1466, p. 14: report of Intelligence Krantzkop, May [27], 1906.

${ }^{78}$ Colenbrander, p. 23. ZA 28: Addison to CNA, May 20 and 21, 1906. Cf. RSC I/1/95: 13/07, R. v. Mahlanza et al.: Mahlanza.

${ }^{79}$ Colenbrander, p. 25. Bosman, pp. 44, 68. Stuart, p. 242. ZA 28: Addison to CNA, May 20, 1906, and CNA to OCZFF, June 2, 1906. CSO 3040 and PM 102: C230/06: OCZFF to Militia, June 5, 1906.

${ }^{80}$ Stuart, p. 259. GH 1465: reports of OCUFF, May 8 (p. 134) and 14, 1906 (p. 146); and 1466, report of Addison, June 6, 1906 (p. 57). UFF Diary, May 13, 1906. Zungu, p. 28. See also the report of the Mgt Emtonjaneni, May 15, 1906, on the state of affairs in his division (ZA 34: C24/06). OD, p. 144: CNA to PM, May 29, 1906. R. v. Kawulana et al.: Zakeli, in records of the Mgt Babanango (1/BGO 1/4/1/1). For attacks on specific persons see Colenbrander, p. 26; CSO 3040 and PM 102: C228/06: CNA to PM, May 26, 1906, and ZA 28: Addison to CNA, May 26, 1906; and SNA I/ 6/29: CR146/07, Adam Sibiya. For the flights of the loyal chiefs Mbuzo, Mpumela, and Ndube, see Colenbrander, p. 20; 1/NKA 3/2/1/2: Report of the Magistrate Nkandhla Division in reply to Circular Commissioner for Native Affairs No. 17/1906, S.N.A. Circular No 11/06, pp. 5, 7 and 9. SNA I/6/27: GH275/06, Ndube; GH 1465: reports of Intelligence Krantzkop, May 15 (p. 148) and Mgt Krantzkop, May 18, 1906 (p. 151). CSO 3040: Mgt Krantzkop to PM, May 16, 1906. For Mangathi's calling for the killing of "traitors", see R. v. Cakijana, 
also reported in September that he did not know of a single instance of women and children left destitute. ${ }^{81}$

Both sides looted stock, generally with success. The trick was to get the stock off before the enemy rallied to recover it. The rebels tried to hide their livestock out of reach of the government forces. A favourite place was the steep, wooded Thathe gorge, but after McKenzie scoured it it was clear that no place was safe from drives. ${ }^{82}$ Distance seemed to offer better protection: at Macala and Kotongweni the government forces were seen coming and large herds were got out of their way during the time it took them to get there. ${ }^{83}$

\section{Rebel revival and defeat}

It is a paradox that in early June as rebel fortunes waned, so they waxed. Rebel strength in the Nkandla forest dwindled owing to heavy losses in men and supplies, yet in the Qudeni it doubled and the rebels even took the offensive.

Mangathi and Bhambatha had just returned from a fruitless visit to Dinuzulu. ${ }^{84}$ Their force was now at the Qudeni, and it was joined at the end of May

172: Mangati; 236: Mafa; 343: Cakijana; R. v. Dinuzulu, 1543: Cakijana; and in the AGO I/7/58 MS: Gekeza; and the statements in AGO I/7/80 of Mangati, Joko, Mbilamqina, Mhlazana, and Ngekeza. On Dinuzulu's opposition to the killing of women and children, see R. v. Dinuzulu, 1186: Daniels.

${ }^{81}$ 1NKA 3/2/1/2 Report of the Magistrate Nkandhla in Reply to Circular Commissioner for Native Affairs No. 17/1906.

82 McKenzie's Report. PM 102: C230/06, OCZFF to Militia, June 1, 1906. Bosman, p. 63. On raiding see GH 1465, p. 117: reports of OCUFF, Apr. 29, and Intelligence Krantzkop, Apr. 30, 1906; and 1466, reports of Intelligence Krantzkop, May [27] (p. 14) and June 9, 1906 (p. 66); UFF Diary, Apr.30 and May 27, 1906; ZA 28: Addison to CNA, May 14, 1906.

83 1/NKA 1/5/1/1, no. 26: R. v. Isolinye et al.: Makolwa. GH 1466, p. 62: Intelligence ZFF, June 7, 1906. In the end even these cattle were taken, probably because there were too few men to move them-see McKenzie's Report, and CSO 3040 and PM 102: C230/06: OCZFF to Militia, June 13, 1906; and also Stuart, p. 335.

${ }^{84}$ The visit remains something of a mystery. See and cf. Stuart, pp. 313-314; Marks, pp. 216-217 and 285-286; and Guy, p. 111, as well as Colony of Natal, The Trial of Dinuzulu on Charges of High Treason at Greytown, Natal, 1908-09 (Pietermaritzburg, Times, 1910; which contains only the indictment, address of counsel for the prosecution and for the defence, and the judgment of the court), pp. 25, 79-83, and xiv-xv. See also CSO 3040: CNA to PM, May 29, 1906. 
by perhaps 350 men from six different tribes of the Dundee, Nqutu, and Umsinga divisions to the North and West of Nkandhla. They had been slow and halting in rebelling, had suffered several reverses, and were being pushed towards the Qudeni by a column of Natal Carbineers advancing in the same direction. Their principal leader was the Ngobese chief Mehlokazulu. ${ }^{85}$

The combination of forces now gave the rebels a local superiority. Raids against loyalists in the area increased. ${ }^{86}$ Bhambatha may have contemplated a thrust into his old location in Natal. ${ }^{87}$ Instead the force moved against the Khabela tribe which had shown great sympathy with the rebellion earlier on, in hope of gaining adherents and also of capturing loyalist cattle which had been moved across the river. The rebels arrived at the Lozeni (Watton's) drift on June $2^{\text {nd }}$, and Mangathi crossed with a small party to parley with the Khabela headman Sitoto, who told him that the tribe was now on the government's side and there were strong government forces on the hills behind it. The rebel delegation recrossed the river and the army

${ }^{85}$ CSO 3040: CNA to PM, May 22, 1906. GH, 1466, p. 42: report of OCZFF, June 1, 1906. Stuart, p. 314. HAZR, pp. 28-29. On Mehlokazulu and the rebellion in the Mzinyathi valley before this time, see Stuart, pp. 266-279, and Marks, pp. 219-222, and for the military operations, HAZR, pp. 20-29; and for the battle of Mpukunyoni (May $28^{\text {th }}$ ), see Stuart, pp. 268-276; Bosman, pp. 56-59; Guy, pp. 111-112; and $H A Z R$, p. 30.

${ }^{86} \mathrm{GH}$ 1466, p. 53: report of OCZFF, June 6, 1906. Colenbrander, p. 25. See HAZR, pp. 34-35, and cf. Guy, pp. 113, 118.

${ }^{87}$ HAZR, pp. 34-35. On Bhambatha's rebel tribesmen still at large in the Mpanza Valley, see reports in GH 1465, of CCP, May 14 (p. 146), and GH 1466, of Addison, May 29 (p. 33) and June 7 (p. 57), OC Greytown, June 8 (p. 62), and Intelligence ZFF, June 9 (p. 66); Natal Mercury, May 24, 1906, "Starvation rampant"; PM 101: C142/06, Addison to CNA, May 31, 1906, and 102: C230/06, OCZFF to Defence, June 9, and reports of D.O. Greytown, June 27, and Intelligence Krantzkop, July 1,1906; and SNA I/1/361: 298/07, Mgt Umvoti to Minister of Native Affairs, Jan. 29, 1907. 


\section{8}

moved to Macala. ${ }^{88}$ The main force from the Nkandla joined it, and the combined force now numbered between twelve and fifteen hundred men. ${ }^{89}$

A plaintive message for help arrived from Sigananda, who had been left to his own devices in the Nkandla. On the night of June $9^{\text {th }} / 10^{\text {th }}$ the army moved towards the forest. ${ }^{90}$ How they would succour Sigananda is not clear. They may have been encouraged to renew the fight in the forest through a misunderstanding of the recent battle of Manzipambana (on June $3^{\text {rd }}$ ): a group of rebels had ambushed a group of militia and levies in the forest: the levies had run away and the militia took casualties for the first time and had to be rescued by reserves. The rebels had been driven off with heavy losses, but for a while they had had the upper hand. In much greater numbers they might engage the militia again in the thick bush, which made men with spears more nearly equal men with guns, and win. ${ }^{91}$ On the other hand, there is evidence suggesting that the army was really going to strike the government force in camp near the grave and to attack the loyalists in the direction of Eshowe. ${ }^{92}$ In either case a victory would revive rebel spirits. It might also raise a rebellion in the Eshowe and Emtonjaneni divisions, where tribes were in an unsettled state because of a rumour that Dinuzulu was coming. ${ }^{93}$ Just a few days ago Mangathi had

${ }^{88}$ Cf. HAZR, pp. 34-35 and Nsuze's account (JSA V, 161) which would date the crossing about June $8^{\text {th }}$, and which Stuart, pp. 314-315, follows. Cakijana's account (Resume) would date it about the $7^{\text {th }}$, but Mangathi (AGO I/7/80, Mar. 27, 1908, and GH 1462 and SNA I/6/29, Dec. 18, 1907) indicates a date earlier in the month, while OC Krantzkop reports (GH 1466, p. 42) on June $2^{\text {nd }}$ the crossing at Watton's Drift and mentions no other crossing thereafter. See also GH 1466, p. 66: report of Intelligence Krantzkop, June 9, 1906, and AGO I/7/80: Mbulali, Mar. 19, 1908.

89 Stuart, p. 316. See also McKenzie's Report; PM 102: C230/06, OCZFF to Defence, June 9, 1906; and GH 1466: reports of Intelligence Krantzkop, June 4 (p. 48) and Intelligence ZFF June 9, 1906 (p. 66).

${ }^{90}$ Stuart, pp. 314-315. JSA V, 161: Nsuze.

91 See and cf. GH 1462 and SNA I/6/29: Mangati, Dec. 18, 1907; R. v. Dinuzulu, pp. 1069, 1071: Mgungulaza; Stuart, p. 316, and Zungu, p. 24. On the battle see Bosman, pp. 69-72; Stuart, pp. 285-293 (who points out that the rebels also had perhaps as many as three dozen firearms); and Guy, pp. 119-120.

${ }^{92}$ See and cf. GH 1466, p. 66: report of Intelligence ZFF, June 9, 1906; SNA I/4/16: C205/06, Addison to CNA, June 15, 1906; and Stuart, p. 316.

${ }^{93}$ Natal Mercury, June 6, 1906: "The Illusive Bambata." ZA 28: CNA to PM, June 12, 1906. ZA 34: CR29/06, Mgt Empangeni to CNA, June 13, 1906. CSO 3040 and PM 102: 229/06, Mgt Eshowe to PM, June 25, 1906. 1/NKA 3/2/2/1: E734/06, Mgt Nkandhla to Mgt Emtonjaneni, July 10, 1906. 
proclaimed that Dinuzulu had ordered him to take command and appointed a new set of leaders for the army. Here already was the influential Zulu chief Mehlokazulu. ${ }^{94}$

Without a clear-cut victory and a massive uprising to give it the range for further operations the army could not survive long. How could it be fed in the recently cleared and driven land? And for all Mangathi's talk about Dinuzulu's revision of command, the councils were still divided. Mehlokazulu enjoyed the greatest prestige, but he showed little generalship. He had refused to support a sally into Natal. The army arrived at the mouth of the Mhome gorge during the night, tired and cold, and did not bother with outposts. Mehlokazulu dismissed reports of an approaching enemy column. Bhambatha stood by him, but Mangathi and Ndabaningi did not: they took their men into the safety of the gorge. ${ }^{95}$ McKenzie's intelligence had learnt of the rebel movement and the columns at Nomangci and near the grave moved by night to intercept it. The result was a surprise attack and the destruction of the rebel army - according to the official estimate 575 were killed, including Mehlokazulu and probably Bhambatha. ${ }^{96}$

The battle - massacre - of Mhome on June $10^{\text {th }}$ signaled the end of the rebellion in Nkandla. ${ }^{97}$ The organization and morale of the rebel army were shattered. The death of Mehlokazulu had much more impact on the Zululand chiefs than that of Bhambatha. ${ }^{98}$ A corpse said to be Bhambatha's was found in the forest, and the head was cut off, brought to camp, and shown privately to those who could identify it and would publicly attest his death. ${ }^{99}$ An armistice was proclaimed to

94 Cakijana states that Mangathi took command (Resume and R. v. Cakijana, pp. 349-350), as does Maginga (in R. v. Sigananda), and Cakijana actually names four new headmen (Resume), but Stuart states (p. 314) that Mangathi said Macala (one of the four named by Cakijana) should take command and Mganu (whom Cakijana does not mention) should command a particular regiment, while Nsuze states (JSA $\mathrm{V}, 162$ ) that Mangathi said both Macala and Mganu should command.

${ }^{95}$ Stuart, pp. 314-316. Resume. PM 104: C238/07, Mangati, Nov. 23, 1907. GH 1462 and SNA I/6/29: Mangati, Dec. 18, 1907. PM 101: C156/06, Addison to CNA, June 11, 1906.

${ }^{96}$ Bosman, pp. 78-93. Powell, pp. 43-48. Stuart, pp. 295-313, 316-317. HAZR, pp. 36, 38-39. Guy, pp. 120-122. McKenzie gave 575 (OCZFF to Cdt, June 11, 1906, in $O D$, p188), which Bosman considers an overestimate (p. 93); Stuart gives about 500 (p. 311).

${ }^{97}$ Bosman, p. 81. Cf. PM 102: C228/06, CNA to PM, June 17, 1906.

${ }^{98}$ PM 102: C228/06, CNA to PM, June 16, 1906. ZA 28: CNA to Addison, June 16, 1906.

99 Cf. Stuart, pp. 366-368, and Guy, pp 128-132; and see also P. S. Thompson, "Bambatha after Mome; Dead or Alive?" 
allow men to surrender - 658 did so by June $21^{\text {st }} \cdot{ }^{100}$ A few bands were seen and several incidents were reported after this, but two government expeditions methodically searched the disaffected area in late June and August and completed the process of pacification. ${ }^{101}$

Sigananda surrendered on June $13^{\text {th }}$ and Ndabaningi on June $16^{\text {th }} \cdot{ }^{102}$ When asked why they had not surrendered after the negotiations in mid-May, Sigananda answered, "You had not fought us then. We were not conquered." 103 And Ndabaningi replied that "the tribe wished to go on fighting as they did not consider themselves beaten but they now realize that they have been." "104 Both were tried by courts martial and found guilty of high treason, but Sigananda died in gaol before sentencing. Ndabaningi was sentenced to death. ${ }^{105}$

\section{Retribution and reconstruction}

McKenzie estimated on June $21^{\text {st }}$ that 1200 rebels had been killed in Zululand. ${ }^{106}$ The magistrate gave exact figures for the tribes of the Nkandhla Division on September $27^{\text {th }}$ : 285 killed and 152 missing, a total of $432 .{ }^{107}$ Martial law, which had been proclaimed in February, was lifted in October. Between June and September eleven courts martials successively tried fifty of the leading rebels and the magistrate's court in fifty-nine trials dealt with about 1500 of the rank and file. 1334 men were convicted. Sentences ranged from imprisonment for one year

${ }^{100}$ PM 102: C230/06, report of OCZFF, June 21, 1906.

${ }^{101}$ For post-Mhome operations see Bosman, pp. 95-105; Stuart, pp. 333-339 and 396-398; and HAZR, pp. 36-37, 40-41, and 60-61.

102 Colenbrander, p. 27.

103 Bosman, p. 110.

${ }^{104}$ McKenzie's Report.

${ }^{105}$ Colenbrander, p. 28. See R. v. Ndabaningi and R. v. Sigananda. On Sigananda's death and burial, see CSO 3040 and PM 102: C229/06: CNA to PM and reply, July 23, 1906; GH 1467, p. 92: Militia to Gov., July 23, 1906; CSO 2599: C147/06, Natal Rangers Diary and Record: Diary of D Company, p. 3.

${ }^{106}$ PM 102: C230/06, report of OCZFF, June 21, 1906.

107 SNA I/1/345: NK 653/06, Statistics In connection with the Native Rebellion 1906 accompanying report by the Magistrate Nkandhla, Sept. 27, 1906 . See Appendix for a breakdown by tribe. The magistrate assigns the killed as follows: Bobe 33, Manzipambana 20, Mhome 164, and elsewhere 68. The figures obviously exclude casualties among men of other divisions, notably Bhambatha's and Mehlokazulu's followers. Subtracting the magistrate's figures from the official estimates for the three battles $(60,525,140)$ we are left with 568 dead, presumably of tribes in other divisions, in and outside of the Nkandhla Division. 
to death (commuted to life imprisonment) for the leaders and from imprisonment for two months to five years for their followers. ${ }^{108}$

The rebellion in the Nkandla had lasted ten weeks. Fortunately it had ended before famine and disease added to death by war. The rebels suffered great deprivation as a result of the government's operations. Some loyalists suffered deprivation as result of rebel operations. The lives of noncombatants were spared. The government was anxious to be as humane as possible given the hard necessities of its strategy and to be seen to be so, but it was ruthless in the destruction or seizure of rebel property. The number of homesteads destroyed was 753 (compared to loyalists' 44). ${ }^{109} 4727$ cattle and 3087 sheep and goats were seized. ${ }^{110}$ The magistrate reported in 1907 :

Owing to the large number of kraals destroyed during the Rebellion of 1906, which have not yet been rebuilt, the male inmates having been imprisoned and the female inmates having left to seek shelter of the kraals of relatives in other Divisions, it is impossible to give, with any regard to correctness, even an approximate estimate of the present native population of the Division. ${ }^{11}$

The government established a Rebellion Losses Claim Board, which met at various places to receive claims, then assessed them, and recommended compensation or not. Which amounts were paid out by the colonial treasury, unless, of course, as in the case of livestock compensation, they could be made from loot stock. There do not appear to be separate statements of compensation by division, and one is left to ferret through long lists of individuals whose places of residence are not given. Assessments for fifteen settlers in the Nkandhla Division amounted to £5377-13-8. ${ }^{112}$ Natives were compensated by the board for losses of huts and livestock. The stock master at the magistracy stated that 358 head of cattle, 235 goats and 37 sheep were issued to natives as compensation, presumably for stock lost. ${ }^{113}$

108 Ibid. CSO 2599: C147/06, Interim Report By Commandant of Militia, Natal, on The Native Rebellion 1906, Appendices E and G. See also Stuart, pp. 404-406.

109 SNA I/1/345: NK 653/06, Statistics.

${ }^{110}$ Natal Defence Records (cited hereafter as NDR) 5/2: V54/07, Statement of Loot Stock taken during the Rebellion. See Appendix for details.

111 AR 1907, p. 113.

112 CSO 3039: Rebellion Losses Claim Board, Second and final Report: Complete Return of Claims, nos. 321-332 and 410-416.

113 NDR 5/2: Nk 88/07. I have found no statements of compensation for huts destroyed. 
Claims by natives for other losses were left to the magistrates to determine. In the case of the Nkandhla Division this involved destroyed grain stores, standing crops, and miscellaneous property in kraals. ${ }^{114}$ The magistrate's assessments totalled £1029-1-3. This seemed excessive to the treasury, which reduced them to £658-18-0, which created bitterness among the loyalists whose expectations had been raised. ${ }^{115}$

There can be no doubt that the economy of the district suffered greatly as a consequence of the war, however brief its duration. Not until 1909 were there as many kraals (2710) as in 1905 (2707). ${ }^{116}$ In the year following the conflict money was scarce, and storekeepers and traders reported little or no trade in native goods. Remittances through the magistracy from inhabitants working outside the division amounted to £224-4-0, compared with £705-5-0 in $1905 .{ }^{117}$ There was a dip in tax collections. The poll tax continued to be collected, but the amount fell from $£ 843$ in 1906 to $£ 378$ in 1907 , although the amount of hut tax was practically the same at $£ 4872-10-0$ and £4869-4-0. ${ }^{118}$ This was because the legislation was amended so that occupants of "bachelor huts" could pay hut tax, which exempted them from poll tax and thus saved them $6 \mathrm{~s} .{ }^{119}$ None the less comparison of the figures for the two years indicates a decrease in the number of payments altogether. Indeed, many hut tax payments were in arrears, until 1909, when the magistrate cracked down and the chiefs fell into line. The amount collected rose from $£ 5195-8-0$ in 1908 to £7303-160 in 1909 , while poll tax collections jogged along at $£ 436$ and $£ 480 .{ }^{120}$

An increasing number of inhabitants sought work outside the division. In 1907 there were 806 identity passes issued and renewed, for work within the Colony (principally in Durban, Pietermaritzburg and Dundee), and 492 outward passes, for work outside the colony, chiefly in Johannesburg. In 19081411 passes were issued and renewed, and in 19091198 passes were issued just to Johannesburg. ${ }^{121}$

\footnotetext{
${ }^{114}$ See p. 15 for damages by mercenary troops.

115 SNA I/1/379: 2876/07, Mgt Nkandhla to CNA, Mar. 5, 1907, and CNA to MNA, Sept. 27, 1907.

116 AR 1909, p. 25.

${ }^{117}$ AR 1907, p. 73.

${ }^{118} A R$ 1907, p. 113.

${ }^{119} A R$ 1907, p. 72. See also HAZR, pp. 62-63.

${ }^{120} A R 1908$, p. 55, and 1909, pp. 27, lxxxv.

${ }^{121} A R$ 1907, p. 72; 1908, p.58; 1909, p. Ixxxvi.
} 
The economy was depressed because of other factors which had nothing to do with war, although they compounded its damaging effects. A large number of people in the lowlands along the Thukela died in a malaria epidemic early in 1907. East Coast fever affecting cattle spread throughout Zululand in 1907. Once infected, there was no saving a herd. Despite efforts of settler and native alike in the division to contain it, over half of the cattle in the division perished by the end of 1908. In 1909 the magistrate reported only 1250 head of cattle in good condition in the division, compared to an estimated 12000 in 1905. Crops, of course, depended on the weather. At the end of the summer in 1907 there was food aplenty in the highlands, but crops in the lowlands had been ravaged by locusts. Early, heavy spring rains brought grub in the maize, but at least the locusts did not return. Evidently the harvest was fair in 1908 , but there was great scarcity, threatening famine, in $1909 .^{122}$

For all this, the magistrate reported that the division had remarkably little crime and stock theft in 1907, and the number of civil cases was only a fifth those in 1905. The trend continued in 1908 and 1909. ${ }^{123}$ But these statistics excluded political crime, and in the wake of the rebellion the Nkandha Division became the focus of what the commissioner called a "reign of terror" against loyalist chiefs. It began in August, when the influential (and energetic) chief of the Sibisi tribe, Sitshitshili, was murdered by an unknown assailant. A fortnight later the police investigating officer was shot at. Early in October attempts were made on the lives of Mapoyisa, son and heir of the Ntuli chief Mbuzo, and another important loyalist of the tribe. At the end of November the other Ntuli chief Mpumela was murdered. Several loyalist chiefs received warnings that they were marked men. Alarm and dismay spread through the ranks of the loyal. ${ }^{124}$

The government proclaimed an amnesty of rank-and-file rebels still at large in October, but it had no effect. ${ }^{125}$ Apparently the cause of disorder was not to be found at this level. The government at last had overwhelming evidence implicating Dinuzulu in the rebellion, ${ }^{126}$ and it decided to act forcefully. At the end of November it ordered his arrest, proclaimed martial law in Zululand, and mobilized militia in support of the police to bring in the Zulu chief and to pacify

\footnotetext{
${ }^{122}$ AR 1907, p 72; 1908, pp. 31, 35; 1909, p. lxxxix.

${ }^{123}$ AR 1907, p. 72; 1908, p.31; 1909, p.lxxxii.

${ }^{124} A R$ 1907, pp. 69-70, 73. See also Stuart, pp. 430-431, 438, and Marks pp. 254261.

${ }^{125}$ AR 1907, p. 70.

${ }^{126}$ See Stuart, pp. 432-437, and Marks, pp. 256-260.
} 
Zululand. ${ }^{127}$ The arrest and the police action in December produced peace almost instantaneously. Loyalists were reassured. Rebels at large returned home. ${ }^{128}$ The government began to release those in prison in batches. ${ }^{129}$ Meanwhile Dinuzulu underwent a long interrogation in 1908 and a long trial in 1908-1909. He was found guilty of complicity in the rebellion, but not of treason, and was sent into exile. $^{130}$

Nkandla returned to peace, and in 1909 the magistrate reported favourably on the natives' good conduct, which he attributed to prompt suppression of the rebellion. ${ }^{131}$ Making an allowance for his telescoping of the government's actions in the statement, he was right. The Nkandhla Division was a crossroads of war geographically, politically and economically. The southern part of the division was crisscrossed by opposing forces many times, and the hapless inhabitants of the district experienced considerable deprivation and displacement. A timely end to the war spared them further, dire consequences.

${ }^{127}$ Stuart, pp. 439-440. Marks, pp. 261-262. HAZR, p. 70. AR 1907, p. 127.

${ }^{128} A R$ 1907, p. 70; 1908, p. 31. Stuart, p. 455.

${ }^{129}$ Stuart, p. 442.

${ }^{130}$ See ibid., chapter 22; Marks, pp. 263-303; and The Trial of Dinuzulu.

${ }^{131} A R$ 190, p. lxxxii. 


\section{APPENDIX}

\section{CHIEFS, TRIBES, KRAALS AND HUTS IN THE NKANDHLA DVISION 1905 AND 1907}

\begin{tabular}{|c|c|c|c|c|c|}
\hline \multirow[t]{2}{*}{ Chief } & \multirow[t]{2}{*}{ Tribe } & \multicolumn{2}{|c|}{1905} & \multicolumn{2}{|c|}{1907} \\
\hline & & Kraals & Huts & Kraals & Huts \\
\hline Sigananda $^{132}$ & Cube & 462 & 1235 & 186 & 508 \\
\hline Mbuzo & Ntuli & 380 & 1062 & 266 & 784 \\
\hline Ndube & Magwaza & 282 & 958 & 72 & 208 \\
\hline Mpumela $^{133}$ & Ntuli & 229 & 659 & 156 & 441 \\
\hline Lukulwini & Biyela & 190 & 622 & 172 & 556 \\
\hline Mtshinane & Kanyile & 230 & 541 & 223 & 545 \\
\hline Mjantshi & Dhlomo & 171 & 488 & 138 & 484 \\
\hline Siyunguza $^{134}$ & Mpungose & 153 & 468 & 134 & 470 \\
\hline Siswana & Biyela & 95 & 355 & 96 & 367 \\
\hline Sitshitshili $^{135}$ & Sibisi & 107 & 341 & 119 & 350 \\
\hline $\begin{array}{l}\text { Matshana } \\
\text { kaSitshikuza }^{136}\end{array}$ & Cunu & 57 & 286 & 60 & 293 \\
\hline Hashi $^{137}$ & Biyela & 81 & 261 & 77 & 270 \\
\hline Nongamulana $^{138}$ & Zondi & 66 & 251 & 58 & 201 \\
\hline Tulwana $^{139}$ & Dhlomo & 86 & 244 & 89 & 230 \\
\hline Makubalo & Kanyile & 69 & 201 & 63 & 181 \\
\hline $\begin{array}{l}\text { Matshana } \\
\text { kaMondisa }^{140}\end{array}$ & Sitole & 49 & 168 & 44 & 130 \\
\hline Mnyakanya $^{141}$ & Nxamalala & -- & -- & 44 & 314 \\
\hline & & 2707 & 8140 & 1997 & 6180 \\
\hline
\end{tabular}

Sources: Colony of Natal, Department of Native Affairs, Annual Reports for the Year 1905 (Pietermaritzburg, Times, 1906), p. 148, and for the Year 1907 (same, 1908), p. 107, using the spelling therein. In the paper a kraal is called a homestead.

\footnotetext{
${ }^{132}$ Died July 22, 1906 (AR 1906, p. 41). No successor is given.

${ }^{133}$ Murdered Nov. 29, 1907 (AR 1907, p. 73).

${ }^{134}$ Died Jan. 3, 1906 (AR 1906, p. 41); Uzinyongo appointed Feb. 17, 1906 (ibid., p. 40).

${ }^{135}$ Murdered Aug. 25, 1907 (AR 1907, p. 73). Macaleni appointed acting chief Nov. 13, 1907 (ibid., p. 111).

${ }^{136}$ Minority of tribe resided in Nqutu Division: 4 kraals and 14 huts in 1905 (AR 1905, p. 149); 3 kraals and 17 huts in 1907 (AR 1907, p. 108).

${ }^{137}$ Resided in Eshowe Division with majority of tribe: 228 kraals and 701 huts in 1905 (AR 1905, p. 147); 269 kraals and 924 huts in 1907 (AR 1907, p. 107).

${ }^{138}$ Resided in Nqutu Division with majority of tribe: 51 kraals and 211 huts in 1905 (AR 1905, p. 149); 50 kraals and 200 huts in 1907 (AR 1907, p. 108).

${ }^{139}$ Died Nov. 23, 1907 (AR 1907, p. 111).

${ }^{140}$ Majority of tribe resided in Nqutu Division: 88 kraals and 267 huts in 1905 (AR 1905, p. 149); 129 kraals and 405 huts in 1907 (AR 1907, p. 108).

${ }^{141}$ Mnyakanya was appointed chief of this new tribe on November 9, 1906 (AR 1906, p. 40).
} 


\section{LOSSES IN THE REBELLION}

\begin{tabular}{|c|c|c|c|c|c|}
\hline \multirow{2}{*}{ Chief } & \multirow{2}{*}{$\begin{array}{l}\text { Kraals } \\
\text { before } \\
\text { rebellion }\end{array}$} & \multicolumn{2}{|c|}{ Kraals destroyed } & \multirow{2}{*}{$\begin{array}{c}\text { Rebels } \\
\text { killed } \\
\& \text { missing }\end{array}$} & \multirow{2}{*}{$\begin{array}{c}\text { Rebels } \\
\text { convicted }\end{array}$} \\
\hline & & $\begin{array}{l}\text { By } \\
\text { Militia }\end{array}$ & $\begin{array}{l}\text { By } \\
\text { Rebels }\end{array}$ & & \\
\hline Sigananda & 471 & 314 & -- & 75 & 437 \\
\hline Mbuzo & 372 & 163 & 29 & 89 & 265 \\
\hline Ndube & 313 & 104 & -- & 99 & 163 \\
\hline Mpumela & 244 & 143 & 5 & 65 & 271 \\
\hline Lukulwini & 196 & -- & -- & 7 & 23 \\
\hline Mjantshi & 165 & 2 & -- & 15 & 10 \\
\hline Uzinyongo & 149 & 1 & -- & 7 & 14 \\
\hline Sitishitshili & 103 & -- & -- & -- & -- \\
\hline Siswana & 90 & -- & -- & 5 & 9 \\
\hline Mtshinane & 230 & -- & -- & 17 & 42 \\
\hline $\begin{array}{l}\text { Matshana } \\
\text { kaSitshikuza }\end{array}$ & 59 & - & -- & - & -- \\
\hline Tulwana & 89 & -- & 2 & 3 & 24 \\
\hline Makubalo & 70 & 15 & 8 & 15 & 26 \\
\hline $\begin{array}{l}\text { Matshana } \\
\text { kaMondisa }\end{array}$ & 56 & 11 & -- & 28 & 43 \\
\hline Hashi & 81 & -- & -- & 10 & 4 \\
\hline Nongamulana & 59 & -- & -- & 2 & 3 \\
\hline & 2747 & 753 & 44 & 432 & 1334 \\
\hline
\end{tabular}

Source: SNA I/1/345: NK 653/06, Statement in connection with the Native Rebellion 1906 accompanying report by the Magistrate Nkandhla, $27^{\text {th }}$ Sept. 1906 . Levies were supplied to the government by the following chiefs (Colenbrander, p. 22): McKenzie's column, Uzinyongo 151, Mjantshi 130, Mtshinana 90, Siswana 58, Sitishitshili 51, Matshana kaSitshikuza 50, Tayiza (of Sigananda) 40; total, 570; Barker's column, Mbuzo 175, Matshana kaMondisa 37, Nongamula 27, Mpumela 16, Tulwana 3, total, 258; Mansel's column, Mfungelwa, about 1000, Lukulwini 168, Ndube 79, Hashi 76, Makubalo 51, total, 1374; grand total, 2202. 


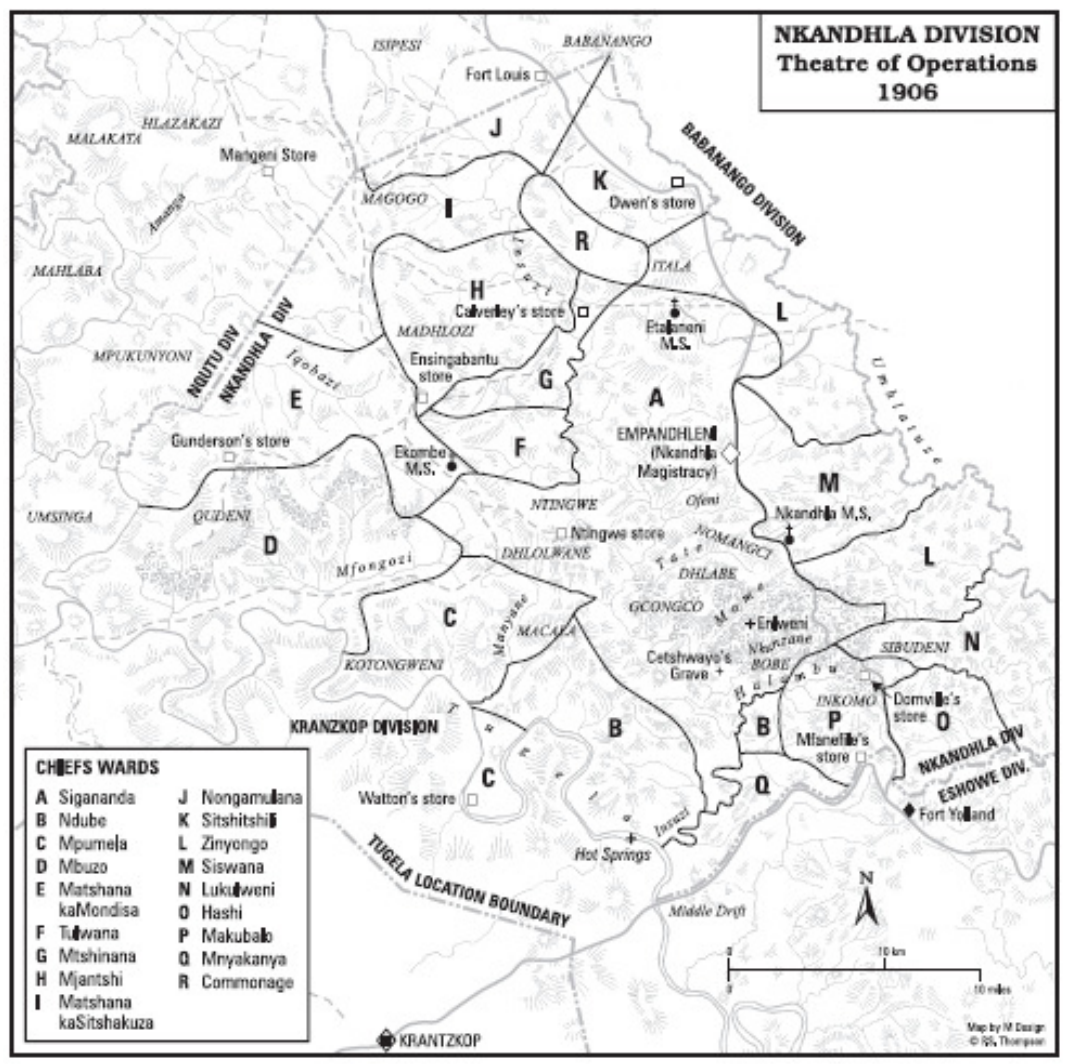

